\title{
INTELLECTUALIZATION OF MONITORING VEHICLES BASED ON THE USE OF PRECEDENTS
}

\author{
V. Pavlenko, Assoc. Prof., Ph. D. (Eng.), \\ Kharkov National Automobile and Highway University
}

\begin{abstract}
The article deals with the intellectualization process of vehicle monitoring through the use of decision support systems for diagnostics of technical condition of vehicles on the basis of precedents. A generalized architecture of a tool program complex to seek solutions on the basis of precedents is proposed. A tool design precedents library is used in intelligent decision support system prototype solutions to meet the challenges of expert diagnosis and operative management of complex objects.
\end{abstract}

Key words: vehicle, operator, system of decision support, diagnosis, expert, precedent, library of precedents, intelligent systems, CBR-cycle.

\section{ІНТЕЛЕКТУАЛІЗАЦІЯ ПРОЦЕСІВ МОНІТОРИНГУ ТРАНСПОРТНИХ ЗАСОБІВ НА ОСНОВІ ВИКОРИСТАННЯ ПРЕЦЕДЕНТІВ}

\author{
В.М. Павленко, доц., к.т.н., \\ Харківський національний автомобільно-дорожній університет
}

Анотація. Розглянуто питання інтелектуалізаиії процесів моніторингу транспорту за допомогою застосування системи підтримки прийняття рішень для діагностики технічного стану автомобілів на основі прещедентів. Запропоновано узагальнену архітектуру інструментального програмного комплексу пошуку рішення на основі прецедентів.

Ключові слова: транспортний засіб, система підтримки прийняття рішень, діагностика, прещедент, бібліотека прецедентів.

\section{ИНТЕЛЛЕКТУАЛИЗАЦИЯ ПРОЦЕССОВ МОНИТОРИНГА ТРАНСПОРТНЫХ СРЕДСТВ НА ОСНОВЕ ИСПОЛЬЗОВАНИЯ ПРЕЦЕДЕНТОВ}

\author{
В.М. Павленко, доц., к.т.н., \\ Харьковский национальный автомобильно-дорожный университет
}

\begin{abstract}
Аннотация. Рассмотрены вопросы интеллектуализации процессов мониторинга транспорта с помощью применения системы поддержки принятия решений для диагностики технического состояния автомобилей на основе прецедентов. Предложена обобщенная архитектура инструментального программного комплекса поиска решения на основе прецедентов.
\end{abstract}

Ключевые слова: транспортное средство, система поддержки принятия решений, диагностика, прецедент, библиотека прещедентов.

\section{Introduction}

Over the past decade in the automotive industry there is a breakthrough in the development of electronic control systems that allow the introduction new technology, are knitted with the management and control of the vehicle and its systems work. Modern diagnostic systems actually generate information in the form of numerical values of diagnostic parameters without specifying the problems that are identified through the analysis of these parameters, an expert who conducts diagnosis that requires appropriate training of specialists, and is associat- 
ed with relatively high labor content and the economic value of the diagnostic work.

\section{Analysis of publications}

Evaluation of technical condition of vehicles is a priority that requires use of specialized decision support systems (DSS). Existing methods of diagnosis do not cover the whole range of external influences which vehicles are exposed during operation. The complexity of solving this problem is caused by a weak formalization of information about the failure, which are describing the nature, the lack of systematic information about the nature and changes in external factors, a large number of monitored parameters and relationships between them, and the lack of statistical data on the operation of the vehicle.

In this regard, only professionals with extensive experience in the diagnosis of specific vehicles, can made a decision on a particular failure is usually finding a solution «by analogy» with pre-failure or malfunction, adapting previously decided in current situation.

So promising is the solution to the problem of diagnostics of vehicles by creating DSS that simulates human reasoning based on the efficient use of existing experience, presented in the form of use cases [1]. This system allows you to summarize information, to adapt to its changes, to communicate with the user in a natural language, decision-making under conditions of incomplete, unreliable and contradictory information.

Availability reasoning mechanism based on precedents in expert diagnosis system allows timely and better quality to carry out diagnostics of vehicles and makes it possible to take appropriate and cost-effective solutions in order to normalize the problem situation [2].

With the emergence of intelligent systems (IS) for different purposes, and the transfer of the center of gravity on the model and knowledge representation and processing methods significantly changing the apparatus of formal considerations, combining a means of reliable and plausible conclusions [3]. Mechanisms of plausible reasoning in IS decision support systems (ISDSS) for monitoring and control of complex objects and processes of different nature, allows for rapid diagnosis of the problem situation and helps decision-makers to choose a suitable alter- native of the possible alternatives when making critical decisions.

\section{Purpose and problem statement}

Purpose of work - solution to the problem of intellectualization of transport monitoring processes through the use of decision support systems for the diagnostics of technical condition of vehicles on the basis of precedents.

\section{Using a precedent for monitoring vehicles}

In most encyclopedic sources precedent (from the Latin «praecedentis» - provisional) is defined as a case that occurred before and that exemplifies or justification for future cases of this kind [2]. The conclusion on the basis of precedents (CBR - Case-Based Reasoning) is an approach that can solve new, unknown problem using or adapting solutions are already known problem that is already using the experience to solve such problems.

An approach based on precedents arising in the development of research in the development of expert systems (knowledge-based). Expert systems were first generation systems based on rules (type of production), which involved a rather well-formalized problems. To solve such problems or methods used reliably concluded that based on the initial data in accordance with the existing set of rules in the system formed opinion on current issues or methods of plausible inference in cases of uncertainty probabilistic nature (bayesovskyy method, based on subjective probabilities, etc. p.).

Unfortunately, most practical tasks aimed at open and dynamic subject areas are poorly formalized, and uncertainty can have probabilistic nature. When seeking a solution of such problems is necessary to use methods of plausible inference that allow us to find some decision (which may not be optimal) solution. One approach is based on the fact that a person (expert, the person who makes the decision (PMD)) typical of the first stage of finding a solution to new (unknown) problem, try the decisions taken earlier in these cases, and if necessary adapt them to the problem (the current problematic situation). This approach using experience formed the basis of considerations modeling techniques based on precedents. 
The basis for the development of this approach and corresponding CBR-systems was the work of R. Schank and R. Abelson [4], which involves problems of memory and knowledge representation. In this paper the present knowledge of problematic situations in the form of so-called stereotypical scripts or scripting events to implement search solutions, forecasting and training. In the early $80 \mathrm{~s} \mathrm{R}$. Schank and his research group at Yale University continue research related to the dynamic memory model and models for reasoning based on precedents, which was realized in the first J. Kolodner CBR-system CYRUS $[5,6]$. Further, these ideas have given rise to the creation of other CBR-systems such as MEDIATOR, CHEF, etc.

Currently, interest in technology and CBRsystems has increased significantly, regularly hosts international conferences and seminars (ICCBR, ECCBR, UKCBR) [7]. Appeared a number of software products, including commercial reasons realizing mechanisms based on precedents - CBR Express, Case Point and ART Enterprise (Inference Corp.), Eclipse - The Easy Reasoner (Haley Enterprises), ReMind (Cognitive Systems Inc .), Apriori (Answer Systems), DP Umbrella (VYCOR Corp.), KATE (Acknosoft), ReCall (ISoft) and others [8]. Methods for reasons based on precedents have been actively used in areas such as medical diagnostics, law, monitoring and diagnostics of technical systems, search for solutions to problem situations, etc. This approach is the basis of machine learning and provides opportunities for the formation of corporate memory.
Typically, the process of withdrawal based on precedents includes four main stages that form the so-called cycle considerations based on case law or CBR-cycle [1], the structure of which is shown in Fig. 1. The relevant literature CBRcycle is also called the cycle of training on precedents (examples). The main stages of CBRcycle are:

- extract the most adequate (like) precedent (or precedent) for the situation with the library precedents (LP);

- re-use remote precedent for attempts to solve the current problems;

- review and adapt, if necessary, of the solution according to the current problem;

- preserving (storing) the decision again as part of a new precedent.

- the method of extraction of precedents on the basis of knowledge (as opposed to the previous method allows to take into account the knowledge of experts (PMD) for a particular domain (coefficients of importance parameters, identifying dependencies, etc.) for withdrawal of cases. The method implements an approach based on indexing precedents special. way (semantic indexing) When determining the precedents taken into account the importance of precedents option is the expert or decision-makers, and other information that allows you to take into account the knowledge of the particular subject area).

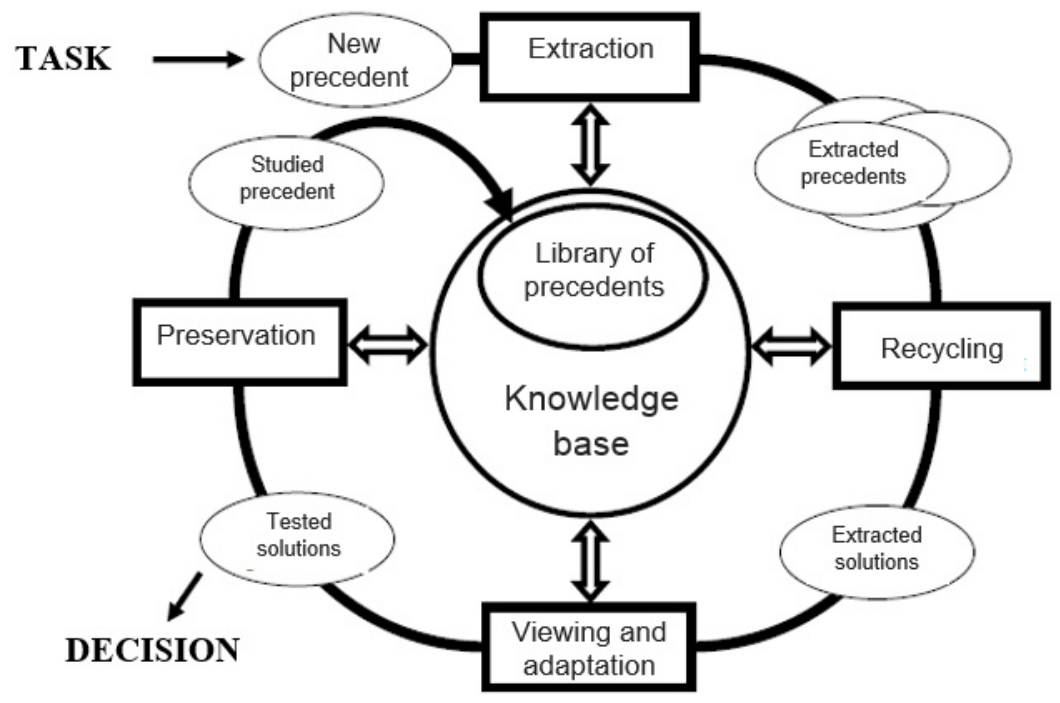

Fig. 1. CBR-cycle 
The benefits of reasons based on precedents include:

- the ability to directly use the experience of the system without intensive involvement of an expert in a particular subject area;

- the possibility of reducing the search time decisions through the use of existing solutions to this problem;

- the possibility of excluding re getting erroneous decision;

- no need for in-depth study and use all available domain knowledge, as can be limited to considering only the essential features of the subject area;

- may use heuristics that increase the efficiency of finding a solution.

The main purpose of using precedents within the vehicle is ready to issue decisions operator (PMD) for the current situation on the basis of precedents that have occurred in the past in the data management or similar object (system).

\section{Methods of extracting and presenting precedents}

In the first stage CBR-cycle - extraction of precedents - is performed to determine the degree of similarity of the current situation with the precedents of LP and their subsequent withdrawal in order to solve this new problem situation. For successful implementation of the arguments based on the case law is necessary to ensure the correct removal of precedents with LP.

The choice of method of receipt precedents directly related to the process of presentation of precedents and thus LP organization. LP may be included in the base system of intellectual knowledge, but can also act as a separate component of the system. Structure LP significantly affects various system operation parameters, and in particular, search and retrieval time precedents. There are different ways of presenting and storing precedents - from simple (linear) to complex hierarchical. Precedent in general can include the following components [1]:

- description of the problem (the problem);

- the solution of problem (diagnosis of the problem situation and recommendations PMD)

- result (or forecast) application solutions.

The result can include a list of actions taken, additional comments and links to other precedents. The precedent may have both positive and negative results of application solutions, in some cases, can be driven justify the selection of the proposed solutions and alternatives. The main ways of presenting precedents can be divided into the following groups:

- parametric;

- object-oriented;

- special (as trees, graphs, logical formulas, etc.).

In most cases, to represent precedents rather simple parametric representation, that is the representation of a precedent in the form of a set of parameters to specific values and the decision (diagnosis and recommendations PMD)

$$
C A S E=\left(x_{1}, \ldots, x_{n}, R\right),
$$

where $x_{1}, \ldots, x_{n}$ - the parameters of the situation, describing the precedent; $x_{1} \in X_{1} \ldots, x_{n} \in X_{n}, n-$ number of parameters precedent; $X_{1}, \ldots, X_{n}$ - the tolerance values of the corresponding parameters; $R$ - diagnosis and recommendations of the decision maker.

There are the following methods for the extraction of precedents and their modifications:

- the method of the nearest neighbor (NN Nearest Neighbor). (The most used method of comparison and extraction precedents It allows easy enough to calculate the degree of similarity of the current problematic situation and precedents with LP to determine the degree of similarity on the set of parameters used to describe the use case and the current situation, introduced a metric. Further, in accordance with the selected metric is determined by the distance from the target point corresponding to the current problematic situation, to the point representing precedents with LP, and the closest point to the selected destination);

- the method of extraction of precedents on the basis of decision trees (based on finding the necessary precedent by addressing the tree tops solutions. Each node of the tree indicates which of its branches should be carried further search solutions. The choice of branches is based on information about the current problematic situation. It is necessary to reach the final the top of which corresponds to one or more of the precedent);

- the method of extraction of precedent with regard to their applicability (in most systems, using reasoning mechanisms based on precedents, it is assumed that the most similar to the current problematic situation precedents and the 
most applicable in this situation. However, this is not always the case. At the core, based on extraction methods the applicability of precedent is the fact that the extraction of precedents based not only on their similarity to the current problematic situation, but also on how well the desired results for the model they represent).

Of the four methods discussed, the most common method is nearest neighbor. The method is based on a specific method for measuring the degree of similarity (closeness) and the precedent of the current problematic situation. Of course, the effectiveness of the method of the nearest neighbor is largely dependent on the choice of the metric.

Selecting appropriate metrics creative and very time-consuming task, the successful solution of which depends the effectiveness of the search and retrieval of cases. In each case, the choice is performed in different ways, depending on the user's objectives (PMD), and the physical nature of the statistical information used in the management of complex objects and other constraints and factors influencing the process of finding solutions. In some methods, the selection of appropriate metrics is achieved by using special algorithms convert attributes of the original space, in others - expert (PMD) itself defines a metric based on their own knowledge of the subject area or the experimental data.

\section{Implementation mechanisms of reasoning based on precedents}

Let's consider a software implementation of mechanisms to find a solution on the basis of precedents in ISDSS. The generalized architecture software tool (the system) to find a solution based on precedents - Constructor LP (CLP) is shown in Fig. 2.

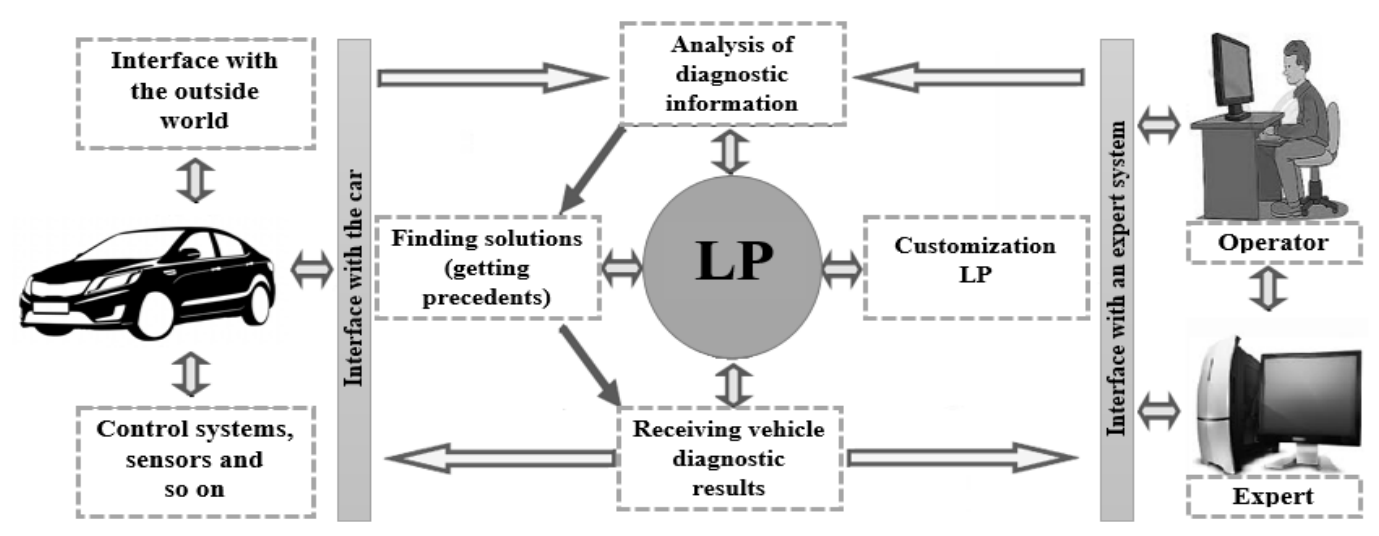

Fig. 2. Software architecture complex KBP

The main components of the CLP, reflecting its functional capabilities are:

- current situation analysis unit on the vehicle, for the pretreatment of object state information (sensor data management system controllers, operative LP, PMD, etc.);

- LP tuner, provides the opportunity to work for LP expert (formation of LP structure, load LP, saving LP, etc.);

- the block to find a solution that implements the mechanisms of plausible reasoning based on precedents (precedents for implementing the withdrawal of the problem situation);

- block delivery of results, outputs results (diagnoses and recommendations) to the user (PMD) to the problem situation based on existing case law indicating the degree of similarity of these precedents to the current situation;

- LP with precedents that have already taken place in the management of the object and its sub-systems, or to ask experts on the basis of his own experience;

- interface with users (experts and PMD), the vehicle and the environment.

The tool CLP is used in the prototype ISDSS to meet the challenges of expert diagnosis and surgical management of complex objects. Under a complex object, it refers to an object that has a complex architecture with a variety of relationships with a large number of controlled and managed parameters and small time of the adoption of the control actions. A typical example of such an object is the vehicle (car). As a rule, complex objects decomposition on technological subsystem (in a car it is a technological subsystems of his system: fuel system, ignition system, cooling system, brake system, etc.) and can be operated in different modes. 
To describe a complex object and its subsystems using a plurality of parameters of ana$\log$, digital, and digital. Condition of object is characterized by a set of values of these parameters. In the operational mode parameters read from the sensors to control the entire object is made by the system controller to time interval through which you need to give the PMD (operator) for a specific diagnosis of the situation and make a recommendation about the necessity of a control action or sequence of actions. Diagnosing and identifying the control actions carried out on the basis of expertise, production schedules and operating instructions [9]. As a general rule, to solve this problem solver used, functioning on the basis of the rules of production type. In the event of abnormal (freelance) situations at the facility there is the need for methods of plausible reasoning, in particular, methods of search solutions based on precedent.

CLP is used to create a LP [10], since the formation of precedents structures, their savings, checking for new precedents for the presence of contradictions (counter examples), further testing LP using the methods of searching for a solution based on precedents (the selection coefficient values the importance of object parameters, determining the source (initial) values of the degree of similarity is adequate metrics for the domain precedent extraction, etc.) and finishing LP retaining it for further use in the operational mode ISDSS functioning.

\section{Conclusions}

In the course of the study it was found that on the basis of precedents diagnostics allows us to solve not fully formalized vehicle diagnostic tasks, simplify the acquisition of knowledge from experts to reduce the search time solutions and implement self. The proposed architecture software system CLP diagnosis of vehicle. The main components, which reflect its functionality, there are precedents base unit settings, and obtain precedents. Application ISDSS reduces the traffic load on PMD in decision-making, reducing the influence of the subjective factors in the analysis of the current situation, reducing the time needed for a decision.

\section{References}

1. Aamodt A. Case-based reasoning: Foundational issues, methodological variations, and system approaches / A. Aamodt,
E. Plaza // AI Communications. - 1994. Vol. 7, Issue 1. - P. 39-59.

2. Варшавский П.Р. Моделирование рассуждений на основе прецедентов в интеллектуальных системах поддержки принятия решений / П.Р. Варшавский, А.П. Еремеев // Искусственный интеллект и принятие решений. - 2009. - № 1. - C. 45-57.

3. Вагин В.Н. Достоверный и правдоподобный вывод в интеллектуальных системах / В.Н. Вагин, Е.Ю. Головина, А.А. Загорянская, М.В. Фомина. - М.: ФИЗМАТЛИТ, 2008. - 704 с.

4. Schank R.C. Scripts, Plans, Goals and Understanding / R.C. Schank, R.P. Abelson. US: Erlbaum, Hillsdale, New Jersey, 1977. $-248 \mathrm{p}$.

5. Kolodner J.L. Maintaining Organization in a Dynamic Long-Term Memory / J.L. Kolodner // Cognitive Science. - 1983. Vol. 7(IV). - P. 243-80.

6. Kolodner J.L. Reconstructive Memory: A Computer Model. / J.L. Kolodner // Cognitive Science. - 1983. - Vol. 7(IV). P. 281-28.

7. CBR-cycle [електронний ресурс]. - Peжим доступу: http://www.iccbr.org/.

8. Watson I. Case-based reasoning: A review. / I. Watson, F. Marir // The Knowledge Engineering Review. - 1994. - Vol. 9, no. 4. - P. 355-381.

9. Геловани В.А. Интеллектуальные системы поддержки принятия решений в нештатных ситуациях с использованием информации о состоянии природной среды / В.А. Геловани, А.А. Башлыков, В.Б. Бритков, Е.Д. Вязилов. - М.: Эдитореал УРСС, 2001. - 304 с.

10. Варшавский П.Р. Методы правдоподобных рассуждений на основе аналогий и прецедентов для интеллектуальных систем поддержки принятия решений / П.Р. Варшавский, А.П. Еремеев // Новости искусственного интеллекта. - 2006. - № 3. - C. 39-62.

\section{References}

1. Aamodt A., Plaza E. Case-based reasoning: Foundational issues, methodological variations, and system approaches AI Communications. 1994. Vol. 7. Issue 1. pp. 39-59.

2. Varshavskyi P.R., Eremeev A.P. Modelirovanie rassuzhdeniy na osnove pretsedentov $v$ intellektualnyih sistemah podderzhki 
prinyatiya resheniy [Modelling of reasoning based on precedents in intelligent decision support systems] Artificial intelligence and decision-making. 2009. no. 1. pp. 4557.

3. Vahyn V.N., Holovyna E.Iu., Zahorianskaia A.A., Fomyna M.V. Dostovernyiy $i$ pravdopodobnyiy vyivod $v$ intellektualnyih sistemah [Reliable and credible conclusion in intelligent systems]. Moscow, FYZMATLYT Publ., 2008. 704 p.

4. Schank R.C., Abelson R.P. Scripts, Plans, Goals and Understanding. US:Erlbaum, Hillsdale, New Jersey, 1977. 248 p.

5. Kolodner J.L. Maintaining Organization in a Dynamic Long-Term Memory. Cognitive Science. 1983, no. 7(IV). pp. 243-80.

6. Kolodner J.L. Reconstructive Memory: A Computer Model. Cognitive Science. 1983, no. 7(IV). pp. 281-28.

7. CBR-cycle: Avialable at: http://www.iccbr.org/.

8. Watson I., Marir F. Case-based reasoning: A review. The Knowledge Engineering Review. 1994. Vol. 9, no. 4. pp. 355-381.
9. Helovany V.A., Bashlyikov A.A., Britkov V.B., Vyazilov E.D. Intellektualnyie sistemyi podderzhki prinyatiya resheniy $v$ neshtatnyih situatsiyah s ispolzovaniem informatsii o sostoyanii prirodnoy sredyi [Intelligent decision support system in emergency situations with the use of information about the state of the environment], Moscow, Editoreal URSS Publ., 2001. 304 p.

10. Varshavskyi P.R., Eremeev A.P. Metodyi pravdopodobnyih rassuzhdeniy na osnove analogiy i pretsedentov dlya intellektualnyih sistem podderzhki prinyatiya resheniy [Methods plausible arguments based on analogies and precedents for intelligent decision support systems] News of artificial intelligence. 2006, no. 3. pp. 39-62.

Рецензент: О.Я. Никонов, профессор, д.т.н., ХНАДУ. 